Clinica Chimica Acta

Elsevier Publishing Company, Amsterdam - Printed in The Netherlands

CCA 5385

\title{
AN AUTOMATED CHROMATOGRAPHIC SYSTEM FOR THE COMBINED ANALYSIS OF URINARY PEPTIDES AND AMINO ACIDS*
}

J. A. KLOSSE, D. Y. HUISTRA, P. K. DE BREE AND S. K. WADMAN

Wilhelmina Children's Hospital, University of Utrecht

AND J. F. G. VLIEGENTHART

Laboratory of Organic Chemistry, University of Utrecht (The Netherlands)

\section{SUMMARY}

An automated system for the combined analysis of urinary peptides and amino acids is presented. Column chromatographic separation is based partially on the Technicon amino acid analysis NC-r method. The column eluate is divided into 2 parts, one for peptide analysis using the Folin-Lowry reaction; the other for amino acid analysis with ninhydrin. Peptide and amino acid peak patterns are registered simultaneously in the same chromatogram.

Aspecific Folin-Lowry-positive substances, as phenols and phenolic acids, are removed by ethyl acetate extraction and macro-molecules with a molecular weight above 15000 by ultrafiltration. Peptide peaks are characterized by relating their position to the positions of the neighbouring amino acids. The Folin-Lowry response/ninhydrin response of tyrosine serves as an internal standard for the colour yield of the peptide peaks.

The peak pattern of normal urines is discussed. Three small groups of patients with "tyrosinosis", coeliac disease and bone disorders are also analysed. Compared with the normals the excretory patterns of the patients show several differences. Abnormal peptiduria can be thus distinguished and abnormal peptide fractions can be recognized, opening the way for isolation and characterization.

\section{INTRODUCTION}

At present column chromatographic urinary amino acid analysis is well developed and has become of great clinical interest. The detailed analysis of urinary peptides is still in an early stage; nevertheless its importance for clinical diagnosis and understanding of disease has been recognized.

It can be questioned to what extent the breakdown of characteristic body proteins ${ }^{1}$ or even peptide hormones ${ }^{2}$ can be traced back by the analysis of urinary peptides. * Correspondence: Dr. S. K. Wadman, Wilhelmina Kinderziekenhuis, Nieuwe Gracht I37,
Utrecht. 
Abnormal peptiduria has been described to occur in bone disease $e^{3-5}$ as a general reflection of increased collagen breakdown, the composition of the peptides containing hydroxyproline (Hyp) being quite characteristic for the mother protein.

In general, proteins having an exclusive composition such as histones or proteins with amino acid sequences resistant to hydrolysis might yield typical peptides. It is known that peptides, deriving from dietary protein digestion in the intestinal Iumen, can be recovered from the urine. Exogenous collagen peptides result from incomplete breakdown of dietary gelatine and other sources of dietary collagen ${ }^{6}$. Gluten peptides with a possibly pathognomonic significance have been described in the blood of patients with coeliac disease ${ }^{7}$ and can be expected to occur in the urine as well.

Systematic urinary analysis for abnormal peptides could demonstrate deficiencies of specific hydrolases similar to AADG-ase deficiency (causing a disturbed breakdown of glycoprotein and an anomalous urinary excretion of AADG: 2 -acetamido-I$\left(\beta^{1}\right.$-L-aspartamido)I,2-dideoxy- $\beta$-D-glucose ${ }^{8}$.

As many different peptides can be expected to occur in urine, methods with a high degree of specificity have to be designed. A sharp characterization of the individual compounds might reveal their relationship to the mother proteins and their significance in disease. This implies that methods have to be developed in which highresolution chromatography is combined with direct detection of the peptides. Such a method has been described by Borel ${ }^{9}$ based on the hypochlorite-tolidine colour reaction. Unfortunately this reaction is rather aspecific: amino acids and conjugates, ammonia compounds, osamines, purines, pyrimidines and some organic acids also give a positive response. Chromatographic methods with indirect detection (alkaline hydrolysis) have been described by Catravas ${ }^{10}$ and Buist et al. ${ }^{11}$. The authors applied ninhydrin detection before and after partial alkaline hydrolysis being an indirect approach. Peptides are recorded as the sum of their amino acids as far as they are liberated; such parameters cannot easily be interpreted quantitatively. Other complications are the interference of conjugated amino acids (glycine and glutamine conjugates or acetyl amino acids). Other detection methods, like U.V. detection and pyrolysis, have well-known shortcomings ${ }^{12-15}$.

In the present paper we describe a combined analysis for peptides and amino acids, based on automated high resolution cation exchange column chromatography. We extended the Technicon $22 \frac{1}{2}$-h AutoAnalyzer NC I procedure. One part of the column eluate is analysed for ninhydrin-positive compounds (amino acids and smal peptides); simultaneously another part is analysed for peptides by a Folin-Lowry procedure, developed for this purpose and adapted for the automated analysis of urinary protein ${ }^{16}$. For both analyses the Technicon continuous flow method was used. There is little or no interference in the peptide pattern by amino acids. It is the possibility to obtain detailed information about free amino acids and peptides during the same analysis that makes the method very attractive.

Prior to chromatographic analysis aspecific substances giving a positive FolinLowry reaction, such as phenols and phenolic acids, are removed by extraction with ethyl acetate. Proteins are removed by ultrafiltration ${ }^{17}$. Only compounds with a molecular weight of less than 15000 are selected for chromatographic separation. Preliminary results obtained from urine of normals and children with various pathological conditions are given in order to demonstrate the possibilities of this analytical system. 


\section{METHOD}

\section{Sample handling}

Ten ml urine is acidified to $\mathrm{pH}$ I. 5 with hydrochloric acid $36 \%$ and subsequently extracted three times with $20 \mathrm{ml}$ ethyl acetate to remove interfering phenolic substances. In a Rotavapor $\left(40^{\circ}\right)$ the volume of the remaining water layer is reduced to I $\mathrm{ml}$. The concentrated solution is ultrafiltered ${ }^{17}$. About $0.2 \mathrm{ml}$ of the filtrate is applied to the column. The time of column chromatographic separation is $22 \frac{1}{2} \mathrm{~h}$.

\section{Column}

Pressure-resistant jacketed glass column $(6 \times 1400 \mathrm{~mm})$; Chromobeads type B cation exchanger; automatic regeneration with $\mathrm{NaOH} 0.2 \mathrm{~N}$, flow $0.56 \mathrm{ml} / \mathrm{min}$.

\section{Elution buffers}

Stock buffer: $73.55 \mathrm{~g}$ trisodium citrate $\cdot 2 \mathrm{H}_{2} \mathrm{O}$ (Merck) is dissolved in $4500 \mathrm{ml}$ aqua bidest; $125 \mathrm{ml} \mathrm{NaOH} 2 \mathrm{~N}$ is added and the solution is boiled for $20 \mathrm{~min}$ to remove ammonia. After cooling the volume is adjusted to $4625 \mathrm{ml}$.

The following buffers are used:

Buffer $\mathrm{pH} 2.875: 1850 \mathrm{ml}$ stock solution is titrated to $\mathrm{pH} 2.875$ with hydrochloric acid $6 \mathrm{~N}$ and the volume adjusted to $2000 \mathrm{ml}$ (sodium $0.20 \mathrm{M}$, citrate $0.05 \mathrm{M}$ ).

Buffer $\mathrm{pH} 3.800: 1850 \mathrm{ml}$ stock solution is titrated to $\mathrm{pH} 3.800$ with hydrochloric acid $6 \mathrm{~N}$ and the volume adjusted to $2000 \mathrm{ml}$ (sodium $0.20 \mathrm{M}$, citrate $0.05 \mathrm{M}$ ).

Buffer $\mathrm{pH}$ 5.000: 70.I $\mathrm{g} \mathrm{NaCl}$ (Baker Chemicals) is dissolved in $1850 \mathrm{ml}$ stock solution and titrated to $\mathrm{pH} 5.000$ with hydrochloric acid $6 \mathrm{~N}$ and the volume adjusted to $2000 \mathrm{ml}$ (sodium $0.80 \mathrm{M}$ citrate $0.05 \mathrm{M}$ ).

Brij 35 gives a white precipitate and thiodiglycol gives rise to some blue colour with the Folin-Lowry reagent, these are therefore omitted.

Gradient eluation is performed with a Varigrad model I30 as given below:

\begin{tabular}{llllllllll}
\hline Chamber & $I$ & 2 & 3 & 4 & 5 & 6 & 7 & 8 & 9 \\
\hline pH $2.875, \mathrm{ml}:$ & 73 & 75 & 75 & 75 & - & 6 & - & - & - \\
pH $3.800, \mathrm{ml}:$ & - & - & - & - & 70 & 9 & - & - & - \\
pH 5.00o, ml: & - & - & - & - & - & 60 & $\underline{75}$ & $\underline{75}$ & $\underline{75}$ \\
\hline Methanol, ml: & 2 & - & - & - & - & - & - & - &
\end{tabular}

\section{Ninhydrin reagents}

Ten $\mathrm{g}$ ninhydrin (Koch-Light), $0.75 \mathrm{~g}$ hydrindantine (Koch-Light). II25 ml distilled methylcellosolve (Shell), I75 ml sodium propionate $(6 \mathrm{M}), 700 \mathrm{ml}$ distilled water. Chemicals).

The sodium propionate is adjusted to $\mathrm{pH} 5.5 \mathrm{I}$ with propionic acid (Baker

\section{Folin-Lowery peptide reagent}

Sodium carbonate, sodium hydroxide solution: Io g anhydrous sodium carbonate (Baker Chemicals) is dissolved in $1000 \mathrm{ml}$ sodium hydroxide o.I $N$.

Copper sulphate solution: $5 \mathrm{~g}$ copper sulphate $\cdot 5 \mathrm{H}_{2} \mathrm{O}$ (Baker Chemicals) is dissolved in rooo $\mathrm{ml}$ of distilled water. 
Sodium potassium tartrate solution: Io g sodium potassium tartrate $\cdot{ }_{4} \mathrm{H}_{2} \mathrm{O}$ (Bater Chemicals) is dissolved in rooo $\mathrm{ml}$ distilled water.

Folin-Cioculteu reagent: The commercially available Folin-Ciocalteu reagent ( $\mathrm{I}$ erck) is diluted with 4 volumes of distilled water and prepared freshly every two days.

\section{General description of the analytical system}

Technicon AutoAnalyzer units are used together with an Intechmij automatic programmer device ${ }^{18}$. The flow diagram is given in Fig. I. After application of the sample, the column is eluted with the buffer-salt gradient $(\mathrm{pH} 2.875-5.000$; sodium $0.20-0.80 \mathrm{M}$ ). The column eluate is split into two parts: $21 \%$ of the volume is used for the ninhydrin detection and $79 \%$ of the volume for the Folin-Lowry detection system. The ninhydrin reaction product is measured at two wavelengths, 440 and $570 \mathrm{~nm}$ in 15 and $8 \mathrm{~mm}$ flow cells respectively.

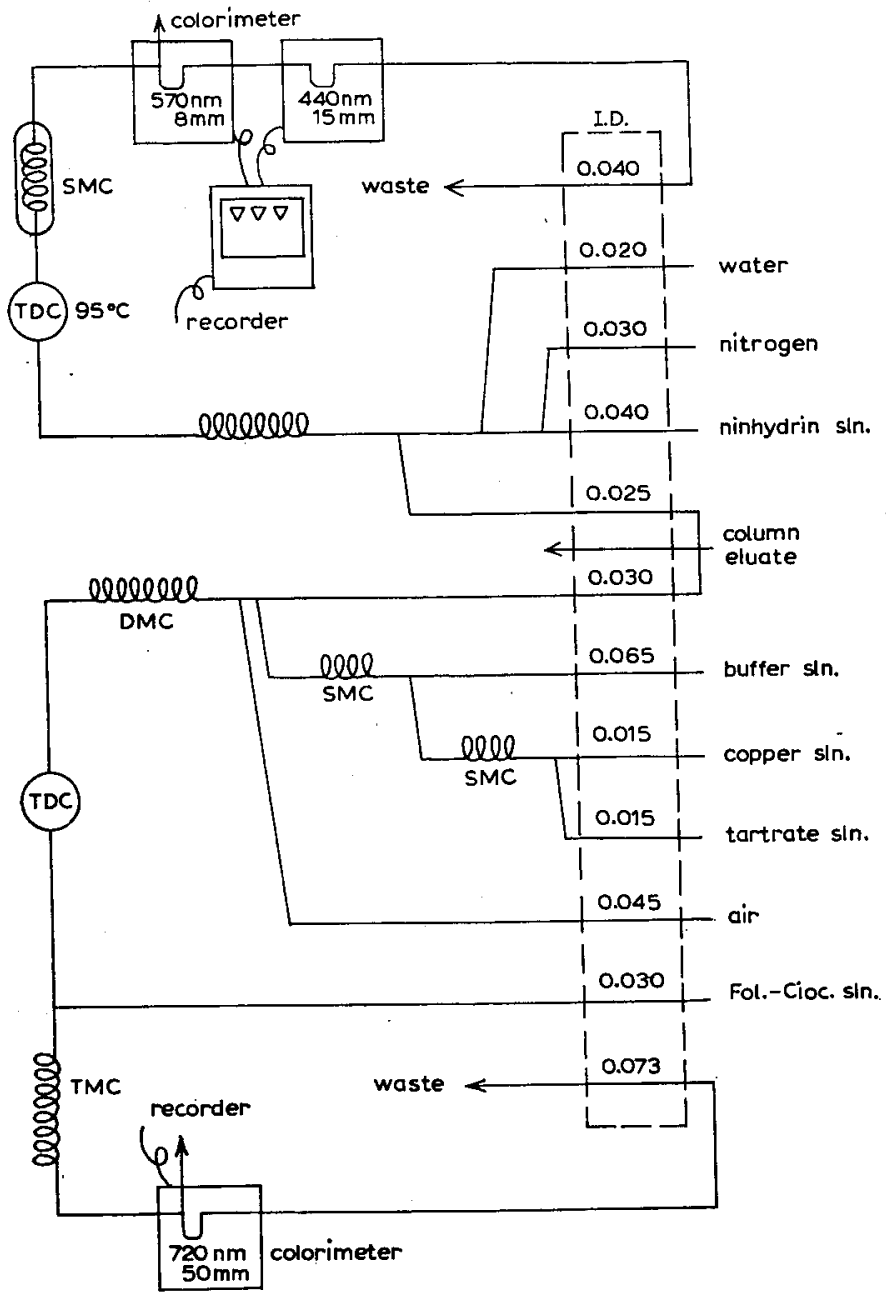

Fig. I. Flow diagram.

Clin. Chim. Acta, 42 (1972) $409-422$ 


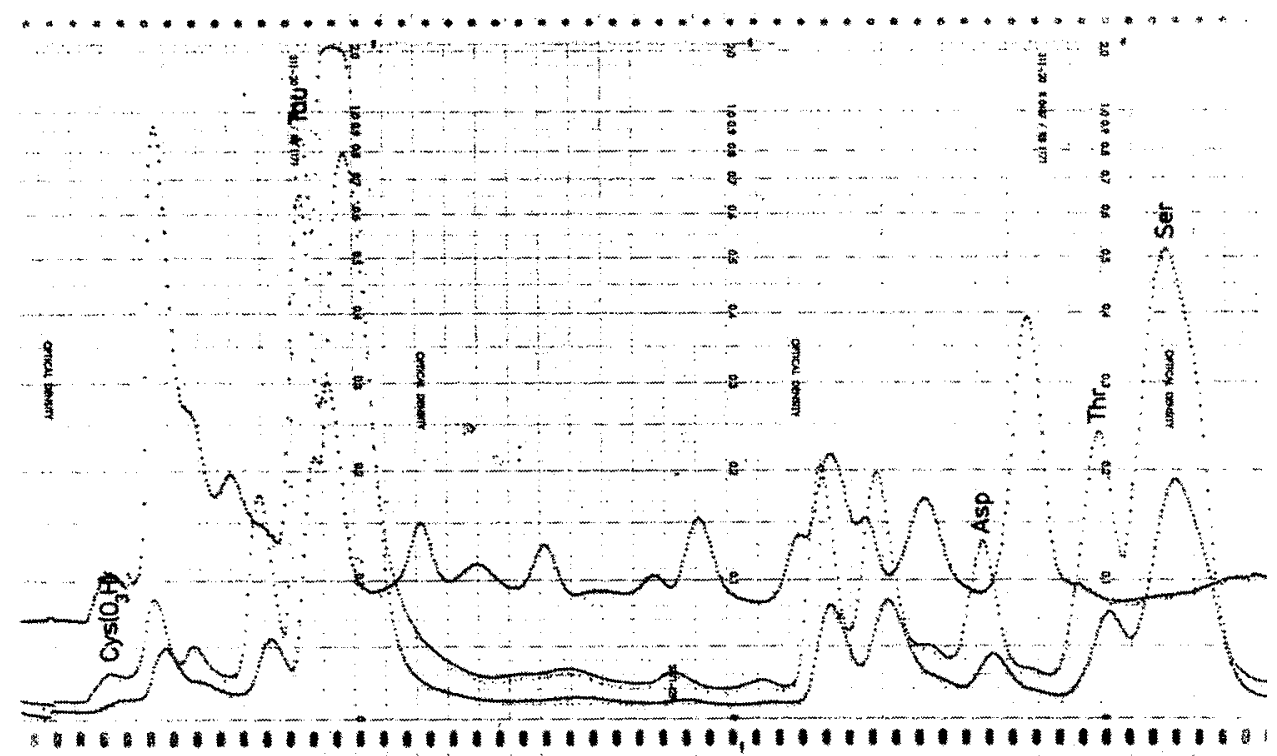

Fig. 2/I Peptide (upper line) and amino acid $\left(57^{\circ}, 44^{\circ} \mathrm{nm}\right.$ lower line) chromatogram

Slight modifications of tubing diameter of the ninhydrin manifold can be seen in Fig. I. Reduction of the flow of the ninhydrin reagent is necessary for phasing amino acids and peptides at the end (see below).

The Folin-Lowry detection is carried out as follows. The sample is complexed with the freshly prepared copper reagent consisting of a mixture of copper sulphate, sodium potassium tartrate and sodium carbonate/hydroxide. The mixture is then passed through a time delay coil (TDC) for $22 \mathrm{~min}$, sufficient for the formation of

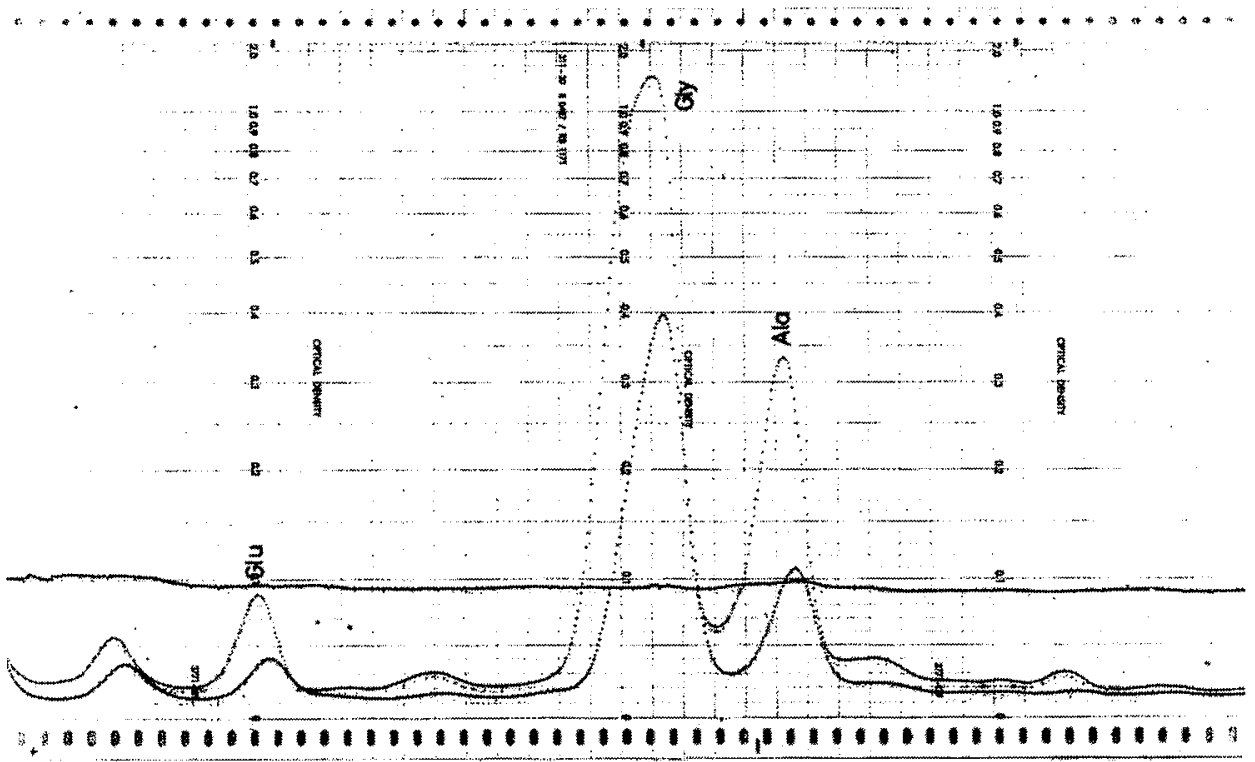

Fig. 2/2 See text Fig. 2/1 

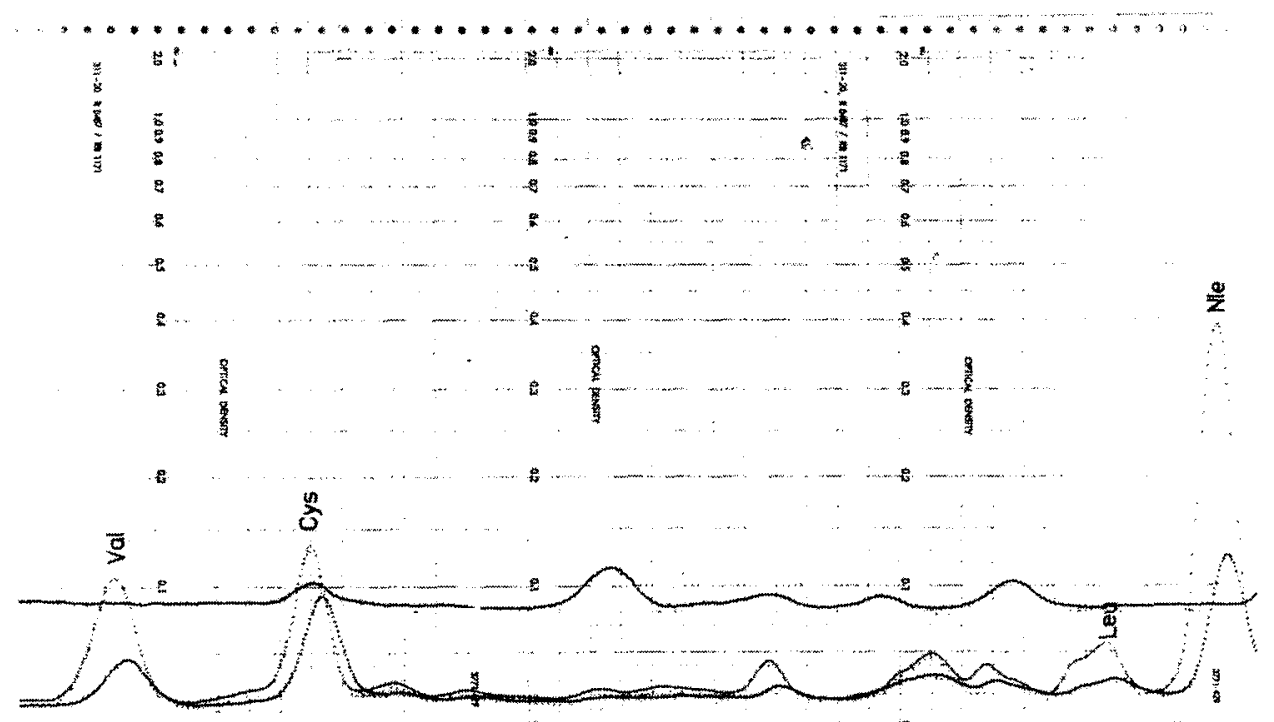

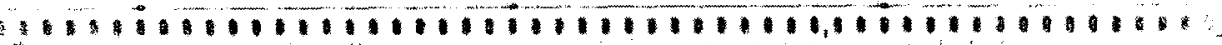

Fig. 2/3 See text Fig. 2/1

peptide-copper chelates. Then the diluted Folin-Ciocalteu reagent is added and after mixing in a TMC $\left(5^{-6} \mathrm{~min}\right)$ the blue reaction product is measured at $720 \mathrm{~nm}$ in a $5^{0-}$ $\mathrm{mm}$ flow cell. The timing of both reaction systems is synchronized in such a manner that the colorimeter signals from the same fraction of the column eluate are recorded simultaneously. This could be effectuated by a favourable choice of time delay coils and reagent flow.
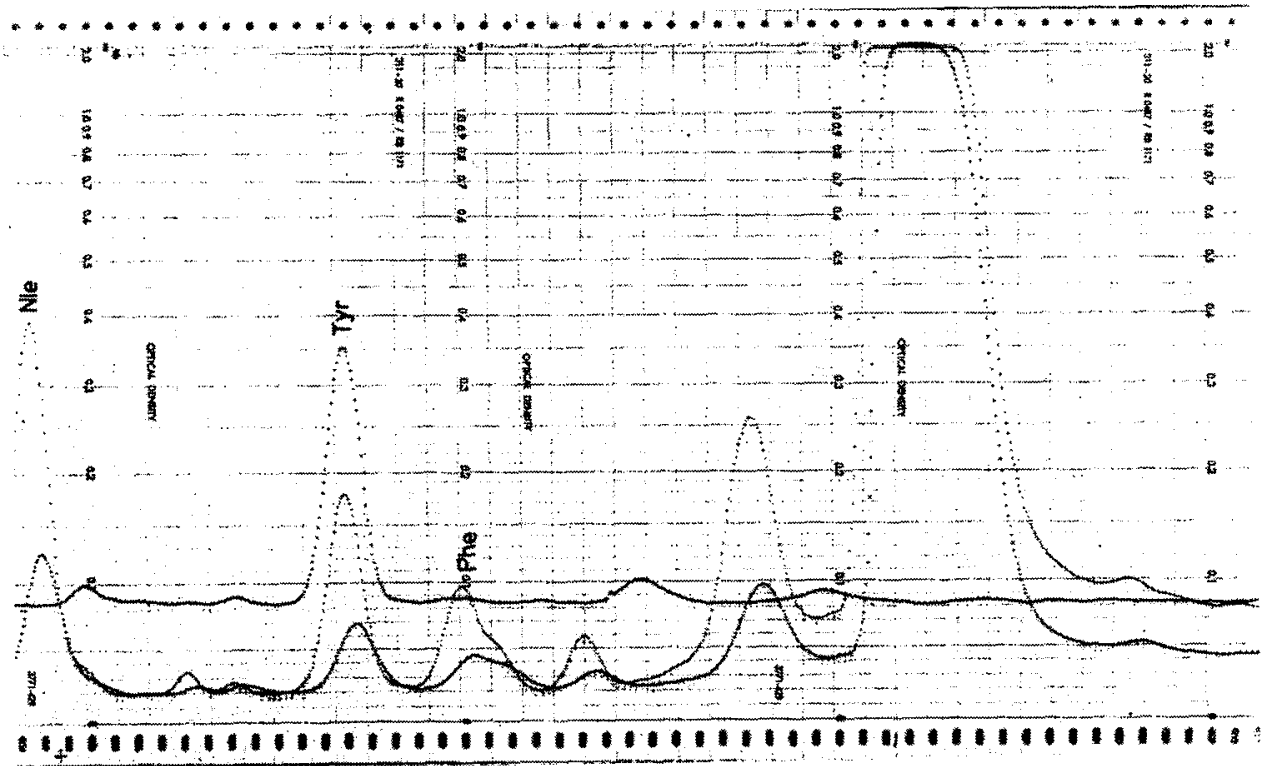

Fig. 2/4 See text Fig. 2/x

Clin. Chim. Acta, 42 (1972) 409-422 


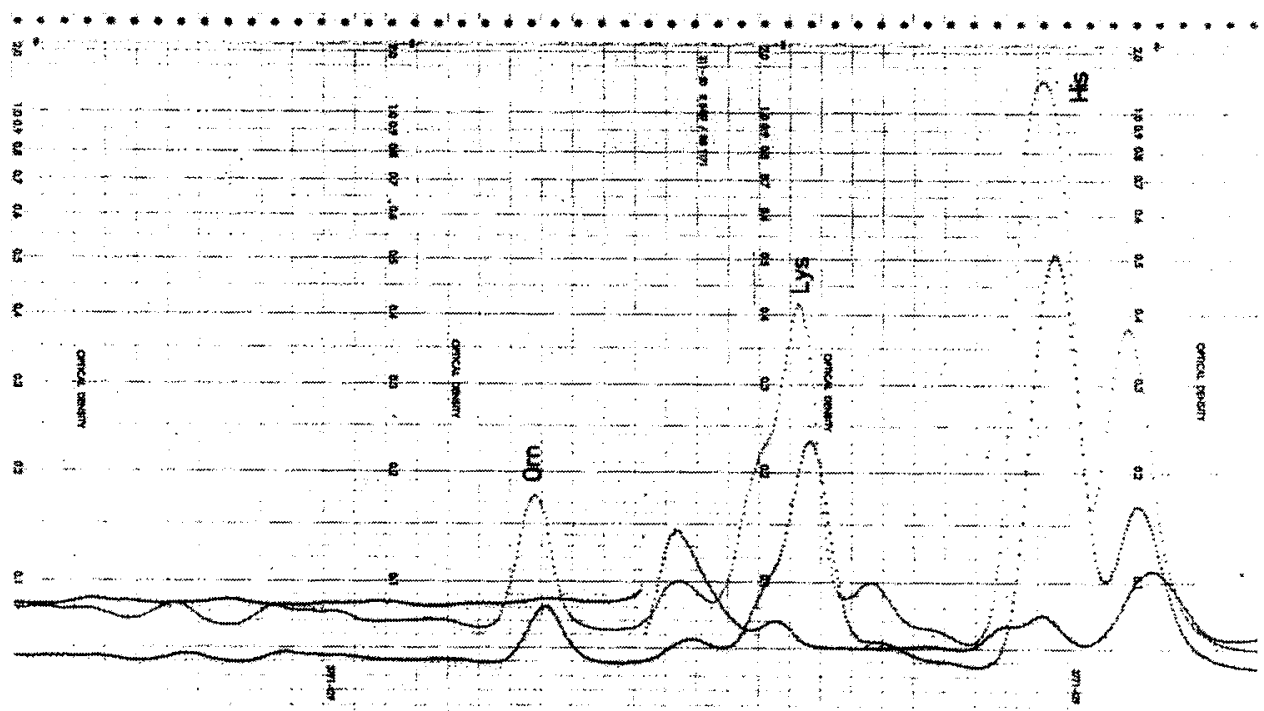

\section{1}

Fig. 2/5 Sec text Fig. 2/I

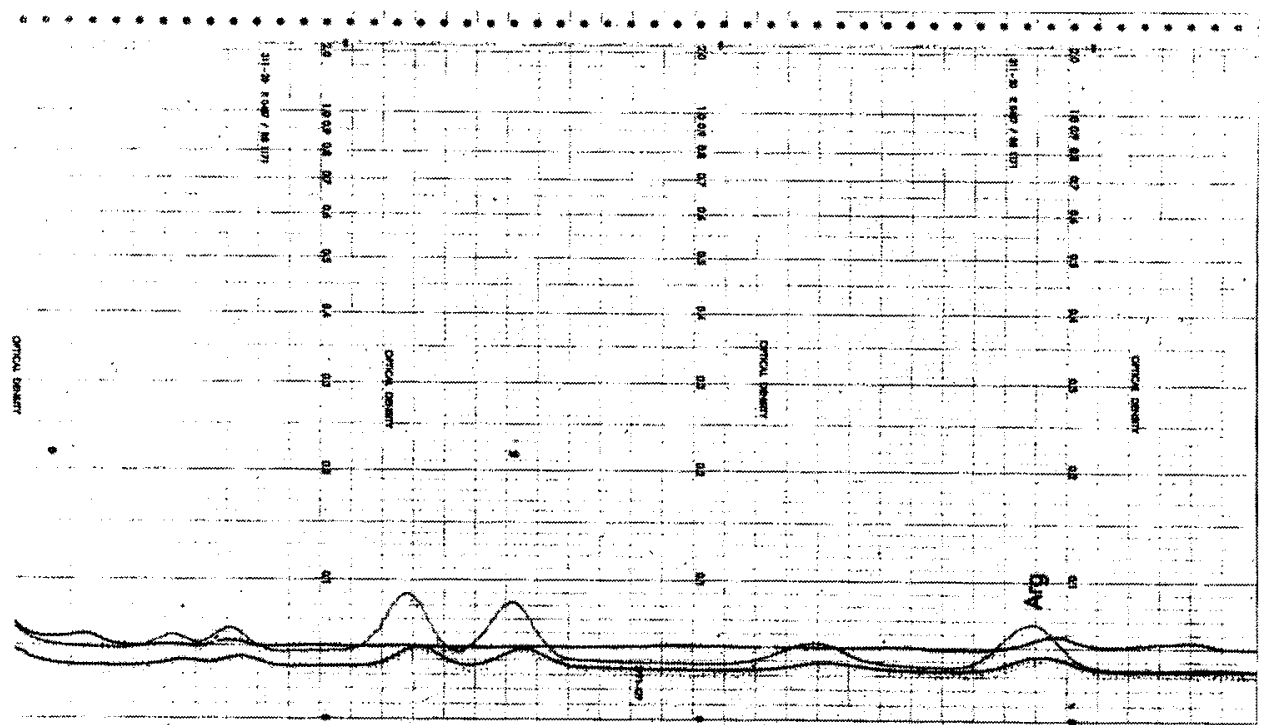

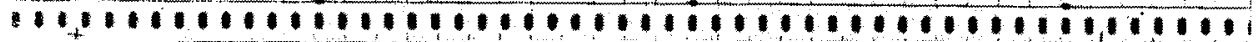

Fig. 2/6 See text Fig. 2/1

RESULTS AND DISCUSSION

Positions of peptides relative to amino acids. Reproducibility

In Fig. 2, a normal chromatogram is shown. The sample was taken fronı a pool of 924 -h urines produced by normal male laboratory workers on an average diet. Some 36 Folin-Lowry-positive peaks, more or less resolved, are present. As these compounds are not yet identified, their position in the chromatogram is the only 
parameter available for their definition. However, the absolute position is liable to considerable fluctuations due to the variability of buffer, salt- and temperature gradients used. Therefore we propose to use the free amino acids as internal position standards. Now the position of each peptide can be related to the neighbouring amino acids on both sides. For calculations a program for the Olivetti Programma ror bench top computer was composed (see ADDENDUM).

\section{TABLE I}

mean positions of amino acids, Relative to Pro (Gly) and Arg.

The chromatogram was obtained from a sample of a pool of 9 24-h urines (see Fig. 2). Mean values ( $\mathrm{mg} / \mathrm{g}$ creatinine) and standard deviations $(N=6)$. Amino acids corrected for internal standard (Nle).

\begin{tabular}{|c|c|c|c|c|}
\hline $\begin{array}{l}\text { Amino acid } \\
N=6\end{array}$ & $\begin{array}{l}\text { Mean position } \\
\text { relative to } \\
\text { Pro(100), Arg } \\
\text { (20o) }\end{array}$ & $S . D$. & $\begin{array}{l}\text { Mean value } \\
\text { expressed as } \\
\text { mg/g creat. }\end{array}$ & $S . D$ \\
\hline $\mathrm{Cys}\left(\mathrm{O}_{\mathrm{a}} \mathrm{H}\right)$ & 71.2 & 2.7 & I.O & 0.0 \\
\hline Tau & 73.9 & 2.6 & $37 \cdot 5$ & I. 8 \\
\hline Asp & 88.4 & I. 7 & 8.0 & I. 4 \\
\hline Thr & 90.2 & 1.6 & I3.I & I.I \\
\hline Ser & $9 \mathrm{I} .4$ & I. 5 & 35.8 & 2.9 \\
\hline Glu & 98.2 & 0.4 & 6.6 & I. 8 \\
\hline Pro & 100.0 & reference & & \\
\hline Gly & 106.I & 0.6 & 59.1 & I.I \\
\hline Ala & 109.3 & I.O & 19.0 & 0.6 \\
\hline Val & I I9.7 & I. 6 & $7 \cdot 3$ & 0.8 \\
\hline Cys & 123.9 & 0.6 & 14.6 & 1.0 \\
\hline Leu & 137.0 & I.O & $3 \cdot 3$ & 0.8 \\
\hline Nle & 139.0 & I.o & $(829$ I.U.) & (I39 I.U.)* \\
\hline Tyr & 143.5 & I.0 & 15.3 & 0.8 \\
\hline Phe & 145.5 & I. 0 & 6.6 & 0.8 \\
\hline Orn & 168.3 & I.I & 6.6 & 0.8 \\
\hline Lys & 173.0 & I. I & 46.0 & 2.0 \\
\hline His & I 79.1 & 0.5 & 108.3 & 3.5 \\
\hline Arg & 200.0 & reference & $3 \cdot 4$ & 0.5 \\
\hline
\end{tabular}

- Peak areas expressed as integration units $/ \mathrm{mg}$ creat.

\section{TABLE II}

SOME WELL DEFINED PEAKS OF THE POOL OF 9 NORMAL 24-h URINES

Mean positions relative to neighbouring amino acids and standard deviations; mean peak areas and standard deviations $(N=6)$.

\begin{tabular}{llll}
\hline $\begin{array}{l}\text { Mean value } \\
\text { relative to }\end{array}$ & $\begin{array}{l}\text { Standard } \\
\text { deviation }\end{array}$ & $\begin{array}{l}\text { Mean value } \\
\text { I.U./mg creat. } \\
\text { Pro(roo), }\end{array}$ & $\begin{array}{l}\text { Standard } \\
\text { deviation }\end{array}$ \\
Arg(200) & & & \\
\hline 73.7 & & 22.4 & 1.6 \\
76.5 & 0.2 & 15.8 & 1.4 \\
80.6 & 0.1 & 2.7 & 0.4 \\
83.2 & 0.3 & 4.0 & 0.3 \\
89.2 & 0.3 & 21.2 & 3.1 \\
I27.7 & 0.5 & 2.6 & 0.2 \\
I72.6 & 0.3 & 7.2 & 0.4 \\
I79.4 & 0.3 & 7.0 & 0.5 \\
Tyrosine & 0.1 & I5.4 & 0.9 \\
\hline
\end{tabular}

c.y.r. Tyr means colour yield ratio of tyrosine (I.U. Folin-Lowry signal of tyrosine per mg creatinine/mg tyrosine per $\mathrm{g}$ creatinine, see text). 
The positions of the amino acids on the time abscissa of the chromatogram are well known. The fluctuations of their positions can be eliminated to a large extent when, arbitrarily, roo respectively 200 time units are chosen for the positions of Pro and Arg. When Pro is absent, Gly (I06.I) can be used instead.

In Table $I$, the relative positions and their standard deviations are given. The fluctuation of the positions of the strongly acidic amino acids as $\mathrm{Cys}\left(\mathrm{O}_{2} \mathrm{H}\right)$ and Tau are highest. In Table II, the reproducibility of the positions of some well resolved Folin-Lowry peaks can be seen.

Considering the results of Tables I and II, we can conclude that the variation of the retention time of the individual amino acids is sufficiently small for preliminary identification. If necessary, a dditional criteria can be used. For automated processing requiring very high precision, the retention time parameter so obtained for the amino acids is still not completely sufficient, so that manual intervention remains necessary. Favourably, the position of the Folin-Lowry-positive peaks related to the neighbouring amino acids appears to be liable to smaller variations than that of the amino acids themselves. Probably the positions of the two amino acids and the intermediate peptide fluctuate in the same direction.

\section{Internal standardization for the colour yield of the Folin-Lowry reaction}

The colour yield is checked by comparing the colour yield for Tyr in both detection systems. Both the Folin-Lowry signal and the ninhydrin signal $(570 \mathrm{~nm})$ are constant during the same analysis. A sensitivity ratio of $37 \times 10^{8} \mathrm{I} . \mathrm{U} . / \mathrm{mg} \mathrm{Tyr}$, S.D. $8 \times 10^{2}$ I.U./mg Tyr ( $=32$ obtained from 32 different urine samples) remains after elimination of differences in light paths and split ratio. The ratio includes all variations: differences in tubing diameter, reaction conditions, composition of reagents, inhomogeneity of the Tyr fraction. The Folin-Lowry reagent is liable to variation due to differences in preparation, ageing and dilution. A six-fold analysis of the same sample showed two significantly different groups of colour yield ratios for Tyr, obviously caused by two different batches of reagent. However, it is possible to correct for variation of the Folin-Lowry signal on a base of a constant ninhydrin signal for Tyr. Nevertheless it should be observed that the Folin-Lowry reaction is very well suited for automation in continuous flow analysis. The reproducibility is much better than with a manual method.

The peak areas are measured with a Technicon Integrator Calculator. The coefficient of variation of the integration procedure is within $3 \%$ of peak area at standard peak magnitude.

\section{Additional remarks concerning the amino acid chromatogram}

The Technicon NC-I 22t-h procedure is a detailed and extensive separation method, which is favourable for the separation of a large number of peptides. However there are certain shortcomings. Asn and Gin decompose for the greater part; Ser is not separated from the remaining Gln. Several peaks are heterogeneous to some extent: symmetrical peaks are obtained from Asp $+\mathrm{Met}\left(\mathrm{O}_{2}\right)$ and from $\mathrm{Val}+\mathrm{Hci}$; asymmetrical peaks from Ser+Gln, Phe $+\beta$ Ala, Lys $+\mathrm{I}-\mathrm{MeHis}$. $\mathrm{Cys}\left(\mathrm{O}_{\mathbf{s}} \mathrm{H}\right)$, Ile and Leu also may show heterogeneity.

In the normal chromatogram (Fig. 2) peaks in the positions of Tau, Met(O), Asp, Cys-Cys and His may be ninhydrin-positive and Folin-Lowry-positive as well, 
possibly indicating a coincidence of amino acids and peptides. Moreover the presence of unknown non-peptidic Folin-Lowry-positive substances must be considered.

\section{Subdivision of the chromatogram}

We propose to distinguish 3 groups of peptides arbitrarily (see Fig. 2, and Table III) : (i) peptides of a mainly acidic character, ranging from the start up to and including Glu; (ii) a group of mainly neutral peptides ranging up to and including Phe; (iii) a group of mainly basic peptides ranging up to the end including Arg.

As can be seen already from the chromatogram shown in Fig. 2, the main poin. of distribution is localized in the acidic fraction, in accordance with the results of Buist et al. ${ }^{11}$.

\section{TABLE III}

QUANTITATIVE INFORMATION ABOUT THE PEPTIDE CHROMATOGRAM

A pool of nine 24-h urine samples from normal adult individuals; r2 patients with various conditions, considered not to give rise to peptiduria, 5 patients with "tyrosinosis", 3 patients with coeliac disease and 3 patients with bone disease, all having peptiduria. Total mean peak area, mean number of peaks and their standard deviations (as far as significant) are given.

\begin{tabular}{|c|c|c|c|c|c|c|c|c|c|}
\hline \multicolumn{2}{|c|}{ Sample } & \multirow{2}{*}{$\begin{array}{l}\text { Total } \\
\text { peak } \\
\text { avea } \\
\text { I.U. }\end{array}$} & \multicolumn{3}{|c|}{ Peak area } & \multirow{2}{*}{$\begin{array}{l}\text { Total } \\
\text { number } \\
\text { of peaks }\end{array}$} & \multicolumn{3}{|c|}{$\begin{array}{l}\text { Number of integratable } \\
\text { peaks }\end{array}$} \\
\hline & & & $\begin{array}{l}\text { acid } \\
f r .\end{array}$ & $\begin{array}{l}\text { neutr. } \\
\text { fr. }\end{array}$ & $\begin{array}{l}\text { basic } \\
\text { fr. }\end{array}$ & & $\begin{array}{l}\overline{a c i d} \\
f r .\end{array}$ & $\begin{array}{l}\text { neutr. } \\
\text { fr. }\end{array}$ & $\begin{array}{c}\text { basic } \\
f r .\end{array}$ \\
\hline I & $\begin{array}{l}\text { Pool } \\
\text { (9 normal } \\
\text { subjects) }\end{array}$ & 4332 & $359 \mathrm{I}$ & $3 \mathrm{I} 7$ & 424 & 36 & $\mathbf{1} 7$ & 9 & Io \\
\hline II & $\begin{array}{l}\text { (I } 2 \text { subjects) } \\
\text { S.D. }\end{array}$ & 6725 & 4696 & $7 I_{4}$ & I3I 5 & 29 & I 4 & 7 & 8 \\
\hline III & $\begin{array}{l}\text { "Tyrosinosis" } \\
\text { (5 patients) }\end{array}$ & $\begin{array}{r}1894 \\
\mathrm{I} 4952\end{array}$ & $\begin{array}{l}\mathbf{1} 508 \\
8957\end{array}$ & $\begin{array}{r}308 \\
1372\end{array}$ & $\begin{array}{r}647 \\
4623\end{array}$ & $\begin{array}{r}5 \\
34\end{array}$ & $\begin{array}{r}2 \\
14\end{array}$ & $\begin{array}{l}2 \\
9\end{array}$ & $\begin{array}{l}3 \\
\text { II }\end{array}$ \\
\hline IV & $\begin{array}{l}\text { Coeliac dis. } \\
\text { (3 patients) } \\
\text { mean of } 4^{24-h} \\
\text { samples }\end{array}$ & I9866 & I5977 & $I_{5} 63$ & 2326 & 40 & I 8 & 9 & I3 \\
\hline V & $\begin{array}{l}\text { Bone dis. } \\
\quad(3 \text { patients })\end{array}$ & 16267 & 8518 & 2275 & 5473 & 28 & IO & 8 & IO \\
\hline
\end{tabular}

In Table III, data are given concerning number of peaks per group and total peak area per group, obtained from 5 populations of chromatograms. In each chromatogram only integratable peaks were considered. (Very small peaks were neglected, whereas partially resolved peaks were integrated as such and taken for one.)

\section{Normal and abnormal excretory patterns}

Population I is a pool of 24-h urines produced by normal male laboratory workers on a normal diet. The data given are mean values obtained from a six-fold analysis (Table II).

Population II consists of twelve 24 -h urines from I2 patients (II children and I adult) with various clinical conditions (psychomotoric retardation, hypsarrhythmia, cystinuria, calcium oxalate lithiasis, congenital lactic acidosis). There was no direct indication for the presence of increased peptiduria. No significant difference from group I was found, with respect to total peak area, peak area per fraction, total peak number and peak number per fraction. 
Population III consists of 5 urine samples of 4 patients with a disease, which in the literature is indicated as "tyrosinosis": M.M. I7 months and H.V. 6 months old, both with a fatal type of tyrosinosis in the terminal stage on tyrosine- and phenylalanine-restricted diet; T.V. I5 months old, elder brother of H.V., with a hereditary tyrosinosis (who responded well to dietary treatment), 2 days respectively I5 days after institution of a tyrosine- and phenylalanine-restricted diet; H.L. aged 5 months, with transient tyrosinosis and renal tubular dysfunction and rickets.

- In these patients total peak area and peak area of each fraction were increased individually (peak position values 7 I.3, 74.6 and 86.I). No significant difference in total peak number and peak number per fraction with respect to populations I and II existed. Especially in this situation it is necessary to be prepared for the presence of non-extractable phenolic compounds arising from the disturbed tyrosine metabolism. However, we found evidence for peptiduria in several experiments:

-In conformity with hydrolysis experiments with pooled urine obtained from normals, the signal decreased by $80 \%$ after hydrolysis.

-There was a remarkable increase compared with the normal urine of nearly all amino acids after hydrolysis (Table IV).

\section{TABLE IV}

INCREASE OF URINARY AMINO ACIDS AFTER HYDROLYSIS IN NORMALS (POOL OF NINE 24-h SAMPLES), IN COELIAC DISEASE, IN BONE DISEASE AND IN TYROSINOSIS. INDICATION FOR THE PRESENCE OF
PEPTIDES

\begin{tabular}{|c|c|c|c|c|c|c|c|c|c|c|}
\hline \multirow[t]{2}{*}{$\begin{array}{l}\text { Amino acid } \\
\text { (in mglg } \\
\text { creatinine) }\end{array}$} & \multicolumn{2}{|c|}{$\begin{array}{l}\text { Normals } \\
\text { (Table } I I I, I)\end{array}$} & \multicolumn{4}{|c|}{$\begin{array}{l}\text { Patient } T . V . \text { with } \\
\text { tyrosinosis }\end{array}$} & \multicolumn{2}{|c|}{$\begin{array}{l}\text { Patient J.D. } \\
\text { with coeliac } \\
\text { disease } \\
\text { before dietary } \\
\text { treatment } \\
\end{array}$} & \multicolumn{2}{|c|}{$\begin{array}{l}\text { Patient M.K. } \\
\text { with osteo- } \\
\text { genesis } \\
\text { imperjecta }\end{array}$} \\
\hline & $\begin{array}{l}\text { before } \\
\text { hydrol. }\end{array}$ & $\begin{array}{l}\text { after } \\
\text { hydrol. }\end{array}$ & $\begin{array}{l}\text { before } \\
\text { hydrol. }\end{array}$ & $\begin{array}{l}\text { after } \\
\text { hydrol. }\end{array}$ & $\begin{array}{l}\text { before } \\
\text { hydrol. }\end{array}$ & $\begin{array}{l}\text { after } \\
\text { hydrol. }\end{array}$ & $\begin{array}{l}\text { before } \\
\text { hydrol. }\end{array}$ & $\begin{array}{l}\text { after } \\
\text { hydrol. }\end{array}$ & $\begin{array}{l}\text { before } \\
\text { hydrol. }\end{array}$ & $\begin{array}{l}\text { after } \\
\text { hydrol. }\end{array}$ \\
\hline $\operatorname{Cys}\left(\mathrm{O}_{3} \mathrm{H}\right)$ & $\mathbf{I}$ & 2 & 29 & 24 & 9 & 8 & Y I & 284 & 34 & I9O \\
\hline Tau & $3^{8}$ & 62 & 7 & $9 \mathrm{r}$ & 3 & 22 & 42 & I 7 I & - & 246 \\
\hline Hyp & o & I 2 & $27^{8}$ & 601 & 0 & 203 & Io & 525 & 239 & I 283 \\
\hline Asp & 8 & 75 & 37 & 653 & $I_{7}$ & I 79 & 65 & 588 & 47 & $74 \mathrm{I}$ \\
\hline Thr & I3 & 21 & - & 3 I2 & 20 & 48 & 42 & II 7 & 38 & 2 I 7 \\
\hline Pro & 0 & 37 & 8 & 655 & 8 & 205 & 0 & 516 & 79 & 984 \\
\hline Gly & 59 & IIO & 337 & $r 860$ & 127 & 300 & 222 & 694 & 528 & I 455 \\
\hline Ala & I9 & 36 & 193 & 364 & $6 I$ & 96 & I $8 \mathrm{I}$ & 412 & 189 & 446 \\
\hline 'Val & $\dot{7}$ & 9 & 22 & II9 & $\mathbf{I} 7$ & 40 & 74 & 72 & 43 & I 20 \\
\hline Leu & 3 & 8 & 77 & I 74 & I2 & 27 & $\mathrm{I}_{4}$ & $5^{6}$ & 24 & 89 \\
\hline Tyr & 15 & I9 & I 29 & $2 \mathrm{I}_{4}$ & 26 & 65 & 68 & 267 & I 53 & 242 \\
\hline Phe & 7 & 8 & 44 & $\mathbf{I} 33$ & I 2 & 24 & 24 & $5^{8}$ & 52 & Ioo \\
\hline Orn & 7 & IO & 23 & 75 & 9 & I7 & $2 I$ & 66 & 24 & 59 \\
\hline Lys & 46 & 74 & $\mathrm{r}_{52}$ & 388 & 69 & I3 8 & I 6I & 549 & 3 IO & 676 \\
\hline $\mathrm{His}$ & 108 & ro4 & 216 & 554 & 65 & I 38 & 684 & 824 & 547 & 882 \\
\hline Arg & 3 & 12 & - & - & I6 & 34 & 57 & -- & I I & $\mathrm{IO} 2$ \\
\hline Total & 334 & 599 & I $55^{2}$ & 6217 & $47 \mathrm{I}$ & I 544 & I 666 & 5 I99 & 2318 & 7832 \\
\hline
\end{tabular}

-Two-dimensional paper chromatography showed unknown ninhydrin-positive compounds. After isolation and hydrolysis especially the amino acids Pro, Hyp, Glu, Gly and. His appeared.

Another indication for the limited interference of phenolic compounds is the experience that in phenylketonuria, an inborn error in which also phenolic compounds are produced in excess, no abnormal peptiduria is found. 
In patient K.v.H., a $5 \frac{1}{2}$-months-old female, increasing peptiduria was found in the terminal stage of illness.

In patients with tyrosinosis the abnormal peptide pattern varied to some extent. In the cases of bone disease increased peptides were merely found in the basic fraction. In tyrosinosis there was a shift to the more acidic region of the chromatogram. In the population III, the peak patterns exhibited slight differences, which can be expected in patients with such a complex syndrome.

In one of the patients (T.V.) peptiduria favourably diminished after installation of a diet low in Phe and Tyr. However, the peptide excretion remained elevated, but on a lower level (Table IV). When the dietary protein hydrolysate was analysed only a minimal peptide signal was seen; a direct contribution of the hydrolysate to the peptide pattern can be neglected.

Population IV consists of $24^{-h}$ urine samples of 3 patients with severe coeliac disease (L.P., female, II months; J.D., female I3 months; E.V., female, I7 months). , All patients showed a subtotal villus atrophy of the jejunal mucosa. One sample of J.D. was collected before institution on a gluten-free diet. The other samples were collected within two weeks after institution on the diet. All of them showed a remarkable increase in total peak area and peak area per fraction, especially peak position values 72.2 and 71.8 were high. There was a small increase in total peak number and peak number in each fraction. The samples (Table III) were studied in

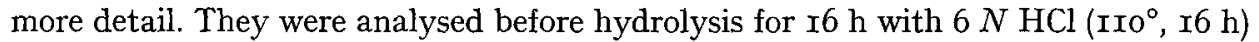
and after mild acidic treatment $\left(0.5 \mathrm{~N} \mathrm{HCl}, 5\right.$ days, $\left.37^{\circ}\right)$. After hydrolysis with $6 \mathrm{~N}$ $\mathrm{HCl}$ there was an impressive increase of several amino acids (mainly $\operatorname{Cys}\left(\mathrm{O}_{3} \mathrm{H}\right)$, Hyp, Asp, Pro, Gly, Ala, Lys and His) indicating massive peptiduria. The peptides may originate from exogenous sources by an exaggerated permeability of the intestinal wall or by a lack of peptidase (E.C. 3. 3.3.4.) activity in the mucosa. However, the presence of bound Hyp points probably to endogenous sources in these young children. Mild acidic treatment resulted in a decrease of the total peptide signal to about half its original value. Mainly in the acidic fraction several peaks disappeared, new peaks arose, and some amino acids increased (Thr, Ser, Tyr, Lys).

Apparently, peptides sensitive to mild acidic treatment are present. However, as a consequence of the mild acidic treatment Gly and His decreased. This could be due to the presence of ninhydrin-positive, Folin-Lowry-negative peptides interfering with the amino acids.

In population $\mathrm{V}, 3$ patients with bone disease were examined. A 2-year-old boy (J.L.) on a collagen-free diet with osteopetrosis showed an elevated peptide pattern (peak position values 86.3 and I79.I were increased). After hydrolysis there was a strong increase of Hyp, Asp, Glu, Pro, Gly, Ala, Lys, His and somewhat less of Tau and Arg. Patient M.K., 2 months old, on a milk diet with osteogenesis imperfecta showed an abnormal peptide pattern (peak position values 86.3 and I79.I were increased) whereas the peak I79.I did not occur in the normals, nor in the patients with tyrosinosis and coeliac disease. After hydrolysis the increase of Hyp, Asp, Glu, Pro and Gly was most impressive, but also Ala, Hyl, Lys and His were high (Table III, IV). Patient H.C., II months old, on a collagen-free diet with rickets showed high values of peptide peaks, like patient M.K. (position values 86.3 and I79.I). As these patients were on a collagen-free diet, we suppose that these peptides are of endogenous origin. 


\section{CONCLUSION}

From the orientational applications described, we can conclude, that with a method reported here it is possible to obtain detailed information about peptiduria. The total peak area, the area per fraction and the area of special single peaks could be shown to be abnormal in the samples of patients specified above.

In patients with tyrosinosis mainly the acidic fraction was elevated. Abnormal single peak positions were 7 I.3, 74.6 and 86.I. On the other hand, these peaks were not considered to be obligatory in this syndrome. In all patients with coeliac disease 2 typical peptide positions were found in the very acid region: 71.8 and 72.2 . In patients with severe bone disease the elevated signal of the basic fraction is remarkable. Typical peak positions were 86.3 and I79.I.

A method as described here can help to find abnormal peptides in the pool of peptides occurring in urine, and possibly to show increased excretion of peptides, both of which may be of pathognomonical significance. Subsequently such peptides should be isolated and analysed in detail.

\section{ADDENDUM}

Olivetti Programma Ior bench top computer program.

$\begin{array}{llll}\text { Problem: } & \mathrm{A}_{1} & \mathrm{X}_{1} & \mathrm{~B}_{1} \\ & \times & \times & \times \\ & \downarrow & \downarrow & \downarrow \\ \times & \times & \times \\ & \mathrm{A}_{2} & \mathrm{X}_{2} & \mathrm{~B}_{2} \\ & \text { Known: } & \mathrm{A}_{1}, \mathrm{X}_{1}, \mathrm{~B}_{1}, \mathrm{~A}_{2}, \mathrm{~B}_{2} \\ & \text { Unknown: } & \mathrm{X}_{2}\end{array}$

Program:

\begin{tabular}{|c|c|c|c|c|c|}
\hline$N$ & Address & Instruction & $N$ & Address & Instruction \\
\hline$I$ & A & V & 22 & & $\mathrm{~s}$ \\
\hline 2 & C/ & * & 23 & D/ & $\uparrow$ \\
\hline 3 & $\mathrm{E}$ & * & 24 & D) & $x$ \\
\hline 4 & E/ & * & 25 & A & 0 \\
\hline $\begin{array}{l}4 \\
5\end{array}$ & & $\mathrm{~s}$ & 26 & C/ & + \\
\hline 6 & B/ & $\uparrow$ & 27 & A & $\diamond$ \\
\hline 7 & & s & 28 & E & $I$ \\
\hline 8 & B & $\uparrow$ & 29 & D & $\downarrow$ \\
\hline 9 & $\mathrm{~B} /$ & $\downarrow$ & 30 & B & - \\
\hline I0 & B & - & $3 \mathrm{I}$ & A & $\diamond$ \\
\hline II & A & $\diamond$ & 32 & E/ & $\tilde{I}$ \\
\hline $\mathrm{I} 2$ & & s & 33 & $\mathrm{E}$ & $\downarrow$ \\
\hline I3 & $\mathrm{C}$ & $\uparrow$ & 34 & E/ & \\
\hline I4 & $\mathrm{C}$ & $x$ & 35 & $\vec{A}$ & $\diamond$ \\
\hline 15 & A & $\diamond$ & 36 & B/ & 8 \\
\hline 16 & C/ & & 37 & $\mathrm{~B}$ & $\Delta$ \\
\hline I7 & & $s^{+}$ & 38 & $\mathrm{C}$ & 0 \\
\hline I 8 & D & $\uparrow$ & 39 & D & 0 \\
\hline I9 & $\mathrm{D}$ & $\downarrow$ & 40 & D/ & 0 \\
\hline 20 & $\mathrm{~B} /$ & - & $4 \mathrm{I}$ & & $\mathrm{V}$ \\
\hline 21 & A & $\diamond$ & & & \\
\hline
\end{tabular}




\section{REFERENCES}

I H. E. Schultze and J. F. Heremans, Molecular Biology of Human Proteins, Vol. I, Elsevier, i.msterdam, I966, p. 487 .

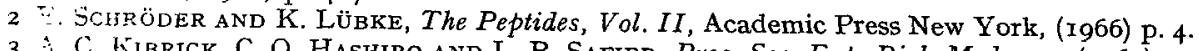

3 A. C. Fibrick, C. Q. Hashiro and L. B. Safier, Proc. Soc. Exp. Biol. Med., rog (I962) 473. $4 \mathrm{i}$. Aiechants, S. J. Skupp, L. B. Safier and A. C. Kibrick, Arch. Biochem. Biophys., 86 (I96o)
7 r.

5 C. R. Scriver, Can. J. Physiol. Pharmac., 42 (I964) 357.

6 D. J. Proeckop, J. Clin. Invest., $43(1964) 453$.

7 O. D. Kowlessar, E. WESER AND L. J. HaEFFNer, J. Clin. Invest., $4 \mathrm{I}$ (1962) 1374.

8 S. Autio, J. Palo, J. K. Visakorpi and M. IIvanainen, Acta Paediat. Scand., 59 (1970) 70. 9 J. P. Borel, M. Desanti, G. Guillaume and J. L. Barascut, Bull. Soc. Chim. Biol., 50 (1968)
$216 j$.

io G. N. Catravas, Anal. Chem., 36 (r964) i 46. i I R. R. M. Buist and J. J. Strandholm, Advan. Autom. Anal., Technicon Intern, Congr., I
(I966) 32r.

I 2 M. M. Mayer and J. A. Miller, Anal. Biochem., 36 (I970) 9 r.

13 C.. A. Burtis and K. S. Warren, Clin. Chem., I 4 (I968) 290. ¿ 4 . Glossmann, E. Köttgen and G. Braunitzer, Hoppe-Seyler's Z. Physiol. Chem., 35 I
(c970) 409.

I5 R. P. W. Scott and J. G. Lawrence, J. Chromatog. Sci., 8 (1970) 65.

I6 J. A. Klosse, P. K. DE Bree and S. K. Wadman, Clin. Chim. Acta, 32 (I97I) $32 \mathrm{I}$.

i G. J. VAN STEKeLENBURG AND J. DesplangUe, Deproteination by Ultrafiltration with Centrifugal Force, Automation in Analytical Chemistry, Vol. II, Technicon International, Ardsley (Chauncey) New York I0502, (1966) p. 439.

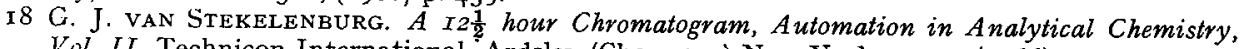
Vol. II, Technicon International, Ardsley (Chauncey) New York I0502, (1966), p. 445.

Clin. Chim. Acta 42 (1972) 409-422 